\title{
OTOLITHOMETRY AND SCALIMETRY-TWO VALID METHODS TO DESCRIBE THE GROWTH OF PEACOCK WRASSE, SYMPHODUS TINCA (ACTINOPTERYGII: PERCIFORMES: LABRIDAE) FROM EASTERN ALGERIA
}

\author{
Naima BOUGHAMOU, Farid DERBAL, and M. Hichem KARA* \\ Marine Bioresources Laboratory, Annaba University Badji Mokhtar, Annaba, Algeria
}

\begin{abstract}
Boughamou N., Derbal F., Kara M.H. 2014. Otolithometry and scalimetry - two valid methods to describe the growth of peacock wrasse, Symphodus tinca (Actinopterygii: Perciformes: Labridae) from eastern Algeria. Acta Ichthyol. Piscat. 44 (4): 285-293.
\end{abstract}

\begin{abstract}
Background. The peacock wrasse, Symphodus tinca (Linnaeus, 1758), is a common Mediterranean fish and the most abundant labrid species on the eastern coast of Algeria. Its age and growth, however, have been poorly studied. Such data are essential for proper fisheries management. The aim of this study is to provide information on the age and growth of this wrasse species from the eastern Algeria based on two different methods of fish age determination.

Materials and methods. Age and growth of Symphodus tinca were determined by examining otoliths and scales of the fish sampled between January and December 2011 on the eastern coast of Algeria. Otoliths and scales from 515 and 469 specimens, respectively, were used to determine the age using commonly accepted procedures.

Results. The age was successfully determined in 513 (99.61\%) otoliths (277 females, 209 males) and in 428 $(91.25 \%)$ scales (232 females, 173 males), representing age classes between $0^{+}$and $5^{+}$years $\left(1^{+}-3^{+}\right.$years for females and $1^{+}-5^{+}$years for males). The validity of the otolith and scale readings for estimating age and growth was supported by the back-calculation method. The success rate in reading otoliths and scales of Symphodus tinca was very high. The growth pattern is well described by the von Bertalanffy growth equation: from otoliths, $L_{\infty}=$ $26.46 \mathrm{~cm}, k=0.79, t_{0}=-0.12$ for females and $L_{\infty}=32.32 \mathrm{~cm}, k=0.54, t_{0}=-0.22$ for males; from scales, $L_{\infty}=$ $26.61 \mathrm{~cm}, k=0.61, t_{0}=-0.45$ for females and $L_{\infty}=32.50 \mathrm{~cm}, k=0.48, t_{0}=-0.31$ for males. Otolithometry and scalimetry gave very close results. The total lengths (TL) ranged from 4.9 to $31.3 \mathrm{~cm}$, and eviscerated weight $\left(W_{\mathrm{e}}\right)$ from 1.38 to $400.65 \mathrm{~g}$. The length-weight relation showed an isometric growth for females $(b=3.01)$, and negative allometric growth for males $(b=2.86)$.

Conclusion. The age was estimated by otolith and scale reading for males and females where the two methods yielded the similar results. Although the otolith readings presented a better fit (99.61\%), scales could also be used with fairly good results $(91.25 \%)$. In the future, research on the growth of S. tinca either of these two methods can be used to save time. The scale method, however, is certainly the easiest.
\end{abstract}

Keywords: otolithometry, scalimetry, wrasse, age, Mediterranean

\section{INTRODUCTION}

The Mediterranean peacock wrasse, Symphodus tinca (Linnaeus, 1758), is a demersal labrid species. It occurs in the eastern Atlantic from northern Spain to Morocco and in the whole Mediterranean, including the Black Sea (Quignard and Pras 1986, Bauchot 1987, Fischer et al. 1987). It is the most common and abundant wrasse in the Mediterranean (Bauchot 1987). This gregarious littoral fish can be found on rocky reefs covered by algae or in sea grass meadows of Posidonia oceanica, sometimes in salty lagoons, at depths ranging from 1 to $50 \mathrm{~m}$ (Quignard and Pras 1986, Bauchot 1987).
The peacock wrasse is a gonochoric species with sexual dimorphism in body colour pattern, which is particularly visible during the reproductive period (Quignard 1966, Warner and Lejeune 1985, Guidetti 2000, Pallaoro and Jardas 2003). Males build nests of seaweeds where one or more females spawn (Warner and Lejeune 1985, Quignard and Pras 1986).

The number of publications covering the age and the growth of Symphodus tinca is limited, despite its wide distribution in the whole Mediterranean. Some general weight-length relations have been published (Petrakis and Stergiou 1995, Dulčić and Kraljević 1996, Gordoa et al. 2000,

\footnotetext{
${ }^{*}$ Correspondence: Prof. Dr M. Hichem Kara, Marine Bioresources Laboratory, Annaba University Badji Mokhtar, Annaba, Algeria, phone: (213) 770312458, fax: (213) 38868510, e-mail: (MHK) kara_hichem@yahoo.com, (NB)boughamounaima@gmail.com, (FD) mfderbal@yahoo.fr.
} 
Morey et al. 2003, Pallaoro and Jardas 2003, Karakulak et al. 2006, İlhan et al. 2008), but only two studies on its age and growth are available, one for Catalan coast (Gordoa et al. 2000) and the another for the Croatian coast (Pallaoro and Jardas 2003).

The age information is important, as it constitutes the basis for the calculations of growth and mortality rates and productivity estimates (Campana 2001), making it essential for fisheries management (Casselman 1987, Tsikliras et al. 2013). One of the main problems facing age and growth estimates is the selection of the morphological structure that would be most suitable for determining the fish age. Scales have been used widely for age estimation, however, the use of scales has been criticized mainly because the ages of older fish are frequently underestimated (Beamish and McFarlane 1983, Carlander 1987). Otolith age determination is thought to be more accurate because otoliths have a higher priority in utilization of calcium (Carlander 1987). Furthermore, scalimetry and otolithometry remain always two methods more usable for estimate age (Beamish and McFarlane 1983, Casselman 1987) but what is the easy and reliable method for determining the age of Symphodus tinca?

This paper investigates age and growth of Symphodus tinca in eastern Algeria. In particular, we compare the results of scalimetry and otolithometry. Growth parameters are essential inputs to stock assessment and will provide better insight into the life history of this species.

\section{MATERIALS AND METHODS}

Samples of Symphodus tinca were collected monthly on the eastern coast of Algeria, between January and December 2011 from the wholesale fish merchants and fishmongers in Annaba city (Fig. 1). The fishermen caught the fish using trammel nets of 35 and $40 \mathrm{~mm}$ mesh size (for individuals larger than $13 \mathrm{~cm}$ ). In addition, some smaller specimens (below $13 \mathrm{~cm}$ ) were obtained by authors using beach seine of 4-mm mesh size and trammel nets of $22 \mathrm{~mm}$ mesh. The latter fish were transported to the laboratory on the day of collection and the following parameters were recorded for each individual: total length (TL; to the nearest $0.1 \mathrm{~cm}$ ), total weight ( $W_{\mathrm{T}}$; to the nearest $0.001 \mathrm{~g}$ ), and eviscerated weight $\left(W_{\mathrm{e}}\right.$; to the nearest $0.001 \mathrm{~g})$. The sex and maturity stage were identified by macroscopic observation of the gonads. Several scales (10-20) were removed from the area below the pectoral fin, washed, and stored dry in individually labelled plastic vials. Sagittal otoliths were extracted by a transverse section on the posterior dorsal part of the head, cleaned in distilled water, and also stored dry in individually labelled plastic vials.

Scales of Symphodus tinca were placed between two glass slides while the otoliths were mounted dry on slides. Both were photographed with a digital camera coupled with a binocular microscope. The photographs taken were digitally processed and used for calibration, measure- ments, and quantification of the growth increments of the calcified structures. The digital processing was aided by the TNPC software v. 5*. All unreadable scales and otoliths were eliminated. Otolith growth increments were counted with the antisulcal face up and from the nucleus towards the post-rostrum end. The radius of the scales was measured along a line running from the focus to the edge of the scale. For each otolith or scale, three readers independently counted the annual growth rings. Otoliths with poorly defined zones were considered unreadable and were discarded. Otolith and scale readings of an individual reader were averaged to obtain the age estimated by that reader. The age estimates were compared between each reader's first-, second-, and third reading and then between the three readers. The precision of estimations was tested by the index of average percentage error (IAPE) (Beamish and Fournier 1981) and the coefficient of variation (CV) (Chang 1982).

Marginal increment analysis was used to validate annual growth increment formation (Beamish and McFarlane 1983). The monthly mean marginal increment (MI) was calculated using:

$$
\mathrm{MI}=\left(r-r_{n}\right) \cdot\left(r_{n}-r_{n-1}\right)^{-1}
$$

where $r, r_{n}$, and $r_{n-1}$ are respectively the radius, the radius of the last-, and the next-to-last growth rings. Monthly values of MI were compared using a one-way ANOVA test, followed by a multiple sample comparison of means (Dagnelie 1975). The function between the total length of fish and the radius of the otolith or the scale was evaluated on the basis of the correlation coefficient $(R)$ or determination coefficient $\left(R^{2}\right)$. Significance of the correlation coefficient was evaluated by Student's $t$-test. The age-length relation was back calculated using Lee (1920) method. Observed lengths at different ages were compared with the back-calculation results by Student's $t$-test. The same test was used to compare males and females growth using back-calculated length at age values. Growth parameters of the von Bertalanffy (1938) equation were estimated:

$$
\mathrm{TL}=L_{\infty}\left(1-e^{-k(t-t 0)}\right)
$$

where $L_{\infty}$ is the asymptotic mean length, $k$ is the growth

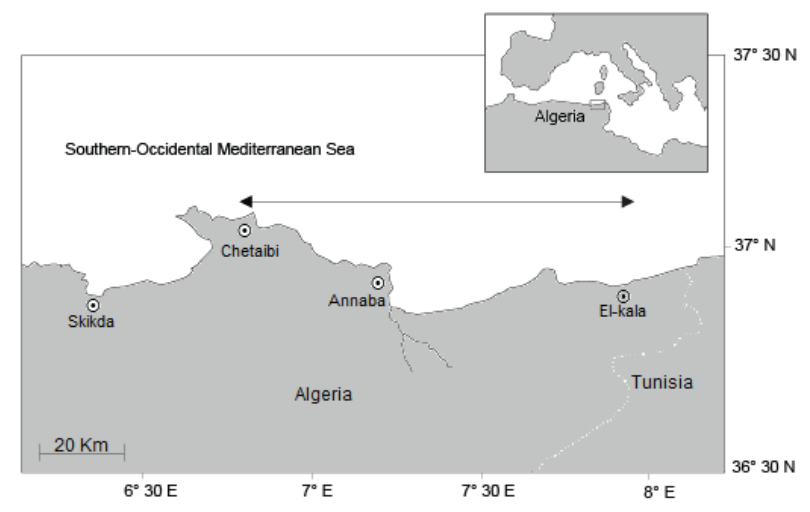

Fig. 1. The sampling range $(\leftrightarrow)$ of peacock wrasse, Symphodus tinca, along the eastern coast of Algeria

\footnotetext{
*Fablet R., Ogor A. 2005. TNPC: Digitised processing for calcified structures. Ifremer - France, Code Lutin, Jean Couteau, Noesis SA.
} 
rate, and $t_{0}$ is the hypothetic age at zero length. The commonly used length-weight relation was applied:

$$
W_{\mathrm{e}}=a \mathrm{TL}^{b}
$$

where $W_{\mathrm{e}}$ is the eviscerated weight [g], $a$ is the intercept, $b$ is the slope (fish growth rate), and TL is the total length $[\mathrm{cm}]$. Difference in the relation of the total length-eviscerated weight between sexes was tested by ANCOVA, and the hypothesis of isometric growth by the $t$-test. The software FISAT II v. 1.2.2 (Gayanilo et al. 1996) was used to estimate the length-weight relation and the growth parameters of the von Bertalanffy (1938) equation. The growth performance index (Pauly and Munro 1984):

$$
\varphi=\log k+2 \log L_{\infty}
$$

was calculated to compare results obtained in this study with results published elsewhere.

\section{RESULTS}

Otoliths and/or scales of Symphodus tinca clearly displayed a concentric pattern of alternating opaque and translucent zones. The opaque zones were deposited mainly in April while the translucent zones deposited down mainly from May to December. Therefore, the formation of growth rings followed a seasonal pattern. The proportion of otoliths with opaque and translucent mar- gins was the highest in April (85.24\%) and March (75.86\%). The results indicated that one opaque and one translucent zone were laid down over a 12-month period and for that reason, represent valid annual growth rings.

Percentage agreements between the readings of the Reader 1 (otoliths: 100\%, scales: 93\%) were much higher than the ones obtained for the less experienced Reader 2 (otoliths: 99\%, scales: 91\%) and Reader 3 (otoliths: 99\%, scales: $90 \%$ ). However, the exact match of the averaged readings between the three readers was relatively high (otoliths: 99\%, scales: 91\%) with quite low values of IAPE (otoliths: $0.01 \%$, scales: $0.24 \%$ ) and CV (otoliths: $0.01 \%$, scales: $0.19 \%$ ). In general, otoliths and scales were easy to read, with clearly identifiable increments.

A total of 515 otoliths and 469 scales were used to determine the fish age. It was successfully determined in 513 (99.61\%) otoliths (277 females, 209 males) (Table 1) and in 428 (91.25\%) scales (232 females, 173 males) (Table 2). The total length of female and male fish ranged from 13.5 to $26.1 \mathrm{~cm}$ and from 13.4 to $31.3 \mathrm{~cm}$, respectively. The total length, otolith radius, and/or scale radius showed a strong linear correlation for females $\left(R^{2}=0.75\right.$, $t$-test $=28.72$ for otoliths, $R^{2}=0.64, t$-test $=20.22$ for scales, $P \leq 0.001)$ and for males $\left(R^{2}=0.75, t\right.$-test $=24.91$

Age length key for females and males of peacock wrasse, Symphodus tinca,

Table 1

\begin{tabular}{|c|c|c|c|c|c|c|c|c|c|c|c|c|c|}
\hline \multirow{3}{*}{$\mathrm{TL}[\mathrm{cm}]$} & \multicolumn{10}{|c|}{ Age [years] } & \multirow{2}{*}{\multicolumn{3}{|c|}{$N$}} \\
\hline & \multirow{2}{*}{$\begin{array}{l}0 \\
\text { I }\end{array}$} & \multicolumn{3}{|c|}{1} & \multicolumn{2}{|c|}{2} & \multicolumn{2}{|c|}{3} & \multirow{2}{*}{$\frac{4}{\sigma^{\lambda}}$} & \multirow{2}{*}{$\frac{5}{3}$} & & & \\
\hline & & $\mathrm{I}$ & q & $\widehat{0}$ & q & $\pi$ & q & 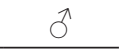 & & & $\mathrm{I}$ & q & 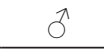 \\
\hline $4-6$ & 3 & & & & & & & & & & 3 & & \\
\hline $6-8$ & 3 & & & & & & & & & & 3 & & \\
\hline $8-10$ & 1 & & & & & & & & & & 1 & & \\
\hline $10-12$ & & 2 & & & & & & & & & 2 & & \\
\hline $12-14$ & & 11 & 10 & 1 & & & & & & & 11 & 10 & 1 \\
\hline $14-16$ & & 7 & 86 & 12 & 7 & & & & & & 7 & 93 & 12 \\
\hline $16-18$ & & & 65 & 21 & 26 & 6 & & & & & & 91 & 27 \\
\hline $18-20$ & & & 16 & 18 & 28 & 3 & & & & & & 44 & 21 \\
\hline $20-22$ & & & & 7 & 21 & 15 & & & & & & 21 & 22 \\
\hline $22-24$ & & & & 2 & 10 & 21 & 4 & 1 & & & & 14 & 24 \\
\hline $24-26$ & & & & 1 & & 23 & 3 & 8 & & & & 3 & 32 \\
\hline $26-28$ & & & & & & 10 & 1 & 27 & 5 & & & 1 & 42 \\
\hline $28-30$ & & & & & & 1 & & 3 & 19 & 2 & & & 25 \\
\hline $30-32$ & & & & & & & & & 1 & 2 & & & 3 \\
\hline$N$ & 7 & 20 & 177 & 62 & 92 & 79 & 8 & 39 & 25 & 4 & 27 & 277 & 209 \\
\hline$\% N$ & 25.92 & 74.07 & 63.89 & 29.66 & 33.21 & 37.79 & 2.88 & 18.66 & 11.96 & 1.91 & 100 & 100 & 100 \\
\hline${ }^{\bar{x}}$ & 6.7 & 13.40 & 15.91 & 16.75 & 21.21 & 22.83 & 24.80 & 26.57 & 28.44 & 30.15 & 10.93 & 18.00 & 22.94 \\
\hline${ }^{1 L} \mathrm{SE}$ & 0.38 & 0.23 & 0.02 & 0.13 & 0.11 & 0.12 & 0.12 & 0.17 & 0.13 & 0.39 & 0.52 & 0.13 & 0.16 \\
\hline$W^{\bar{x}}$ & 4.87 & 36.90 & 64.26 & 81.65 & 105.00 & 173.15 & 183.96 & 250.14 & 313.53 & 365.82 & 25.10 & 73.05 & 180.86 \\
\hline$W_{\mathrm{e}} \mathrm{SE}$ & 0.87 & 2.00 & 1.14 & 3.88 & 2.84 & 6.31 & 10.83 & 6.52 & 6.03 & 17.61 & 3.37 & 1.94 & 6.38 \\
\hline
\end{tabular}
from eastern Algeria, based on otolith readings

$\mathrm{TL}=$ total length, $\mathrm{I}=$ immature, $q=$ female, $\widehat{\delta}=$ male, $\bar{x}=$ mean, $\mathrm{SE}=$ standard error, $W_{\mathrm{e}}=$ eviscerated weight, $N=$ number of fish. 
for otoliths, $R^{2}=0.73$, $t$-test $=21.50$ for scales, $P \leq 0.001$ ). The equations expressing the linear relation between the total length (TL) $[\mathrm{mm}]$ and the otolith radius $(r)$ were:

- females: $\mathrm{TL}=89.78 r+18.44$,

- males: $\mathrm{TL}=98.97 r+20.44$,

and these expressing the linear relation between the total length (TL) $[\mathrm{mm}]$ and the scale radius $(r)$ were as follows: - females: $\mathrm{TL}=32.77 r+19.01$,

- males: $\mathrm{TL}=28.52 r+19.04$.

A one-way ANOVA applied to mean values of the marginal increment (MI) indicated their significant heterogeneity $(F=73.74$ for MI of otoliths, $F=66.05$ for MI of scales, both $P<0.0001)$. Comparing successive monthly mean marginal increment values of otoliths and scales using mean comparison tests showed a significant difference between March and April (Fig. 2). Thus, the rings were considered to be annual increments. The high percentage of otoliths and scales with hyaline edges was observed at the end of the winter and the beginning of spring (March). The lowest values of marginal increment were recorded in April, which is considered to be the period of annulus formation for Symphodus tinca in the study area.

Age range of the sampled fish was $0^{+}-5^{+}$years, with predominance of age classes of $1^{+}-2^{+}$years for females (otoliths: 97.11\% individuals, scales: $96.55 \%$ individuals) and $1^{+}-3^{+}$years for males (otoliths: $86.12 \%$ individuals, scales: $83.23 \%$ individuals). The oldest female was estimated to be $3^{+}$years, and the oldest male $5^{+}$years (Tables 1 and 2 ). Back-calculated lengths obtained by the Lee's equation are given in Table 3. Observed lengths at different ages did not vary significantly with the back-calculation

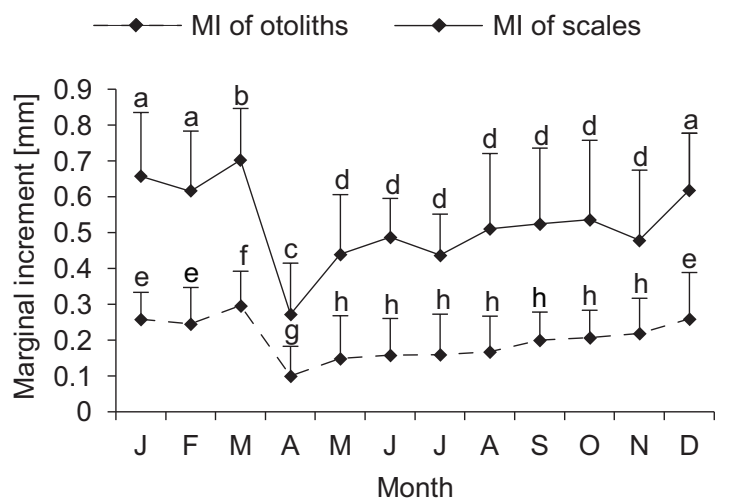

Fig. 2. Monthly evolution of the marginal increment (MI) of peacock wrasse, Symphodus tinca, from eastern coasts of Algeria; The different letters indicate significant differences between sampling points

Table 2

Age length key for females and males of peacock wrasse, Symphodus tinca, from eastern Algeria, based on scale readings

\begin{tabular}{|c|c|c|c|c|c|c|c|c|c|c|c|c|c|}
\hline \multirow{3}{*}{$\mathrm{TL}[\mathrm{cm}]$} & \multicolumn{10}{|c|}{ Age [years] } & \multirow{2}{*}{\multicolumn{3}{|c|}{$N$}} \\
\hline & \multirow{2}{*}{$\begin{array}{l}0 \\
\mathrm{I} \\
\end{array}$} & \multicolumn{3}{|c|}{1} & \multicolumn{2}{|c|}{2} & \multicolumn{2}{|c|}{3} & \multirow{2}{*}{$\begin{array}{l}4 \\
\end{array}$} & \multirow{2}{*}{$\begin{array}{l}5 \\
\end{array}$} & & & \\
\hline & & $\mathrm{I}$ & q & $\pi$ & q & $\pi$ & q & $\pi$ & & & $\mathrm{I}$ & q & $\pi$ \\
\hline $4-6$ & 3 & & & & & & & & & & 3 & & \\
\hline $6-8$ & 2 & & & & & & & & & & 2 & & \\
\hline $8-10$ & 1 & & & & & & & & & & 1 & & \\
\hline $10-12$ & & 2 & & & & & & & & & 2 & & \\
\hline $12-14$ & & 12 & 8 & 3 & & & & & & & 12 & 8 & 3 \\
\hline $14-16$ & & 3 & 42 & 5 & 40 & 7 & & & & & 3 & 82 & 12 \\
\hline $16-18$ & & & 19 & 5 & 66 & 20 & & & & & & 85 & 25 \\
\hline $18-20$ & & & & 4 & 32 & 15 & & & & & & 32 & 19 \\
\hline $20-22$ & & & & 3 & 12 & 15 & 1 & 2 & & & & 13 & 20 \\
\hline $22-24$ & & & & & 4 & 6 & 3 & 9 & & & & 7 & 15 \\
\hline $24-26$ & & & & & 1 & 6 & 3 & 20 & 2 & & & 4 & 28 \\
\hline $26-28$ & & & & & & 3 & 1 & 17 & 11 & & & 1 & 31 \\
\hline $28-30$ & & & & & & 1 & & 3 & 12 & 2 & & & 18 \\
\hline $30-32$ & & & & & & & & & & 2 & & & 2 \\
\hline$N$ & 6 & 17 & 69 & 20 & 155 & 73 & 8 & 51 & 25 & 4 & 23 & 232 & 173 \\
\hline$\% N$ & 26.08 & 73.91 & 29.74 & 11.56 & 66.81 & 42.19 & 3.44 & 29.47 & 14.45 & 2.31 & 100 & 100 & 100 \\
\hline \multirow{2}{*}{ 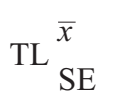 } & 6.55 & 13.37 & 15.36 & 15.94 & 20.31 & 21.68 & 24.33 & 25.44 & 28.24 & 30.07 & 11.59 & 18.03 & 22.38 \\
\hline & 0.23 & 0.21 & 0.12 & 0.24 & 0.08 & 0.14 & 0.27 & 0.10 & 0.18 & 0.42 & 0.47 & 0.12 & 0.19 \\
\hline \multirow{2}{*}{$W_{\mathrm{e}}^{\bar{x}}{ }_{\mathrm{SE}}$} & 4.74 & 36.20 & 50.75 & 71.63 & 96.91 & 114.58 & 180.60 & 208.61 & 289.37 & 353.91 & 27.99 & 72.36 & 168.13 \\
\hline & 1.10 & 1.83 & 1.48 & 6.28 & 2.31 & 7.26 & 14.89 & 6.02 & 5.73 & 13.34 & 3.26 & 2.21 & 6.83 \\
\hline
\end{tabular}

$\mathrm{TL}=$ total length, $\mathrm{I}=$ immature, $q=$ female, $\bar{\delta}=$ male, $\bar{x}=$ mean, $\mathrm{SE}=$ standard error, $W_{\mathrm{e}}=$ eviscerated weight, $N=$ number of fish sampled. 
lengths for males and females (Table 4). The back-calculated length at age did not significantly differ between sexes (unpaired $t$-test, all $P>0.05$ ) for otoliths (1 year: $t$-test $=0.791,2$ years: $t$-test $=0.855,3$ years: $t$-test $=$ 1.021) and scales (1 year: $t$-test $=1.013,2$ years: $t$-test $=$ $0.721,3$ years: $t$-test $=0.941)$. The estimated parameters of the von Bertalanffy model and the growth performance index $(\varphi)$ are given in Table 5. The calculated asymptotic lengths (otoliths: $L_{\infty}=26.46 \mathrm{~cm}$ for females and $L_{\infty}=$ $32.32 \mathrm{~cm}$ for males; scales: $L_{\infty}=26.61 \mathrm{~cm}$ for females and $L_{\infty}=32.50 \mathrm{~cm}$ for males) agree well with the maximum observed lengths ( $\mathrm{TL}=26.1 \mathrm{~cm}$ for females, $\mathrm{TL}=31.3 \mathrm{~cm}$ for males). The estimated parameters of the von Bertalanffy growth model suggested that the growth of Symphodus tinca was relatively fast in first two years of life with males growing at slightly slower rate and attaining slightly larger sizes than females.

Sample sizes $(N)$, parameters $a$ and $b$ of the length weight relations, the standard error of the slope $(s)$, and the determination coefficient $\left(R^{2}\right)$ of Symphodus tinca are presented in Table 6 . The slopes ( $b$ values) of the total length-weight relations, which differ significantly between sexes (ANCOVA, $F=8833.27, P<0.0001$ ), indicate allometric growth for males and isometric growth for females. The value of $b$ was significantly different from 3.0 for males $(t$-test $=2.45, P \leq 0.05)$ but not for females $(t$-test $=0.32, P>0.05)$.

\section{DISCUSSION}

The maximum total length of the peacock wrasse, Symphodus tinca, recorded in the Mediterranean Sea was $44.0 \mathrm{~cm}$ (Bauchot 1987). In the presently reported study it amounted to $31.3 \mathrm{~cm}$. The latter value is lower than that reported by Pallaoro and Jardas (2003) (42.5 cm), Quignard and Pras (1986) (35 cm), and Tortonese (1975) $(35 \mathrm{~cm})$ in middle eastern Adriatic, southern of France and Italy coasts, respectively, but higher than the values recorded by Dieuzeide et al. (1955) $(30 \mathrm{~cm})$ and Svetovidov (1964) $(30 \mathrm{~cm})$ in Algerian coasts and Black Sea, respectively. These differences could be due to a biogeographic difference in growth rate (Caselle et al. 2011), but also to differences in local fishing pressure (Weijerman et al. 2013).

Otolith and scale marginal increment values of Symphodus tinca suggest that only one growth ring is formed yearly in April. The high percentage of otoliths and scales with hyaline edges observed at the end of the winter and the beginning of spring could be related to physiological stress during the spawning season (March-June) (Dieuzeide et al. 1955). These months also constitute the

Table 3

Back-calculated lengths at age for males and females of peacock wrasse, Symphodus tinca, in eastern Algeria based on otolith- and scale readings

\begin{tabular}{|c|c|c|c|c|c|c|c|c|c|c|c|c|}
\hline & \multirow{2}{*}{ Sex } & \multirow{2}{*}{ Age } & \multicolumn{2}{|r|}{ TL1 } & \multicolumn{2}{|r|}{ TL2 } & \multicolumn{2}{|r|}{ TL3 } & \multicolumn{2}{|r|}{ TL4 } & \multicolumn{2}{|r|}{ TL5 } \\
\hline & & & $N$ & $\bar{x} \pm \mathrm{SE}$ & $N$ & $\bar{x} \pm \mathrm{SE}$ & $N$ & $\bar{x} \pm \mathrm{SE}$ & $N$ & $\bar{x} \pm \mathrm{SE}$ & $N$ & $\bar{x} \pm \mathrm{SE}$ \\
\hline \multirow{10}{*}{ 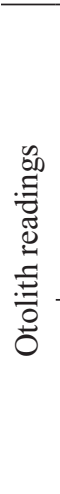 } & \multirow{6}{*}{$\frac{\infty}{\sqrt{\pi}}$} & $1^{+}$ & 62 & $16.17 \pm 0.09$ & & & & & & & & \\
\hline & & $2^{+}$ & 79 & $16.12 \pm 0.05$ & & $21.22 \pm 0.12$ & & & & & & \\
\hline & & $3^{+}$ & 39 & $16.28 \pm 0.08$ & & $22.66 \pm 0.08$ & & $26.68 \pm 0.07$ & & & & \\
\hline & & $4^{+}$ & 25 & $16.03 \pm 0.11$ & & $23.14 \pm 0.07$ & & $25.44 \pm 0.1$ & & $26.65 \pm 0.04$ & & \\
\hline & & $5^{+}$ & 4 & $16.16 \pm 0.07$ & & $22.09 \pm 0.31$ & & $26.34 \pm 0.32$ & & $28.5 \pm 0.43$ & & $30.04 \pm 0.26$ \\
\hline & & Total & 209 & $16.15 \pm 0.04$ & 147 & $22.58 \pm 0.06$ & 68 & $26.32 \pm 0.08$ & 29 & $28.2 \pm 0.09$ & 4 & $30.04 \pm 0.26$ \\
\hline & \multirow{4}{*}{$\begin{array}{l}\frac{\mathscr{d}}{\tilde{\Xi}} \\
\frac{0}{0} \\
\text { I. }\end{array}$} & $1^{+}$ & 177 & $15.51 \pm 0.01$ & & & & & & & & \\
\hline & & $2^{+}$ & 92 & $16.74 \pm 0.01$ & & $20.9 \pm 0.12$ & & & & & & \\
\hline & & $3^{+}$ & 8 & $15.81 \pm 0.13$ & & $21.58 \pm 0.32$ & & $24.15 \pm 0.4$ & & & & \\
\hline & & Total & 277 & $15.24 \pm 0.02$ & 100 & $21.21 \pm 0.11$ & 8 & $24.15 \pm 0.4$ & & & & \\
\hline \multirow{10}{*}{ 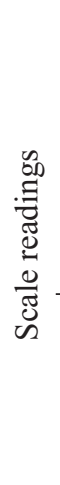 } & \multirow{6}{*}{$\frac{\infty}{\frac{\infty}{\pi}}$} & $1^{+}$ & 20 & $14.73 \pm 0.21$ & & & & & & & & \\
\hline & & $2^{+}$ & 73 & $15.07 \pm 0.09$ & & $19.32 \pm 0.11$ & & & & & & \\
\hline & & $3^{+}$ & 51 & $14.77 \pm 0.09$ & & $19.77 \pm 0.02$ & & $23.88 \pm 0.11$ & & & & \\
\hline & & $4^{+}$ & 25 & $16.59 \pm 0.1$ & & $22.62 \pm 0.22$ & & $25.95 \pm 0.13$ & & $27.81 \pm 0.18$ & & \\
\hline & & $5^{+}$ & 4 & $16.53 \pm 0.35$ & & $23.1 \pm 0.42$ & & $26.11 \pm 0.44$ & & $28.43 \pm 0.39$ & & $30.01 \pm 0.6$ \\
\hline & & Total & 173 & $15.54 \pm 0.07$ & 153 & $21.2 \pm 0.04$ & 80 & $25.31 \pm 0.03$ & 29 & $28.12 \pm 0.18$ & 4 & $30.01 \pm 0.6$ \\
\hline & \multirow{4}{*}{ 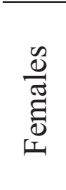 } & $1^{+}$ & 69 & $14.45 \pm 0.12$ & & & & & & & & \\
\hline & & $2^{+}$ & 155 & $16.36 \pm 0.02$ & & $19.95 \pm 0.02$ & & & & & & \\
\hline & & $3^{+}$ & 8 & $15.61 \pm 0.18$ & & $20.79 \pm 0.13$ & & $24.29 \pm 0.15$ & & & & \\
\hline & & Total & 232 & $15.35 \pm 0.04$ & 163 & $20.3 \pm 0.02$ & 8 & $24.29 \pm 0.15$ & & & & \\
\hline
\end{tabular}

$\mathrm{TL}=$ total length, $N=$ number of fish sampled, $\bar{x}=$ mean, $\mathrm{SE}=$ standard error, TL1 through TL5 are the backcalculated sizesat-age. 
period in which the temperatures in the Gulf of Annaba are the lowest (close to $16^{\circ} \mathrm{C}$, Frehi et al. 2007).

Otolith age determination is supposed to be more accurate compared to the scale-base method because otoliths have a higher priority in utilization of calcium (Carlander 1987). In our case, these calcified structures were clear and easy for reading with a high readability and they did not require a long time to read. The interpretation of the calcified structures of Symphodus tinca was largely successful, with only $0.4 \%$ of otoliths and $9 \%$ of scales being rejected.

Despite all this, the scales gave us good results of age determination. Symphodus tinca age estimation revealed similar results both for otolith and scales readings. The back-calculated length at age did not significantly differ between sexes for otoliths and scales. The highest estimated age was $5^{+}$years for males and $3^{+}$years for females. Quignard and Pras (1986) and Bauchot (1987) reported that in the Mediterranean Sea the life span for both sexes reached $14^{+}$to $15^{+}$years while growth rates were slow: $7^{+}$year-old females and males reached $20 \mathrm{~cm}$ and $26 \mathrm{~cm}$,

Comparison of the observed lengths at different ages with back-calculation lengths for peacock wrasse,

Symphodus tinca, from eastern Algeria

\begin{tabular}{|c|c|c|c|c|c|c|}
\hline RM & Age & Sex & Observed length & Back-calculated length & $t$ & $P$ \\
\hline \multirow{8}{*}{$\begin{array}{l}\frac{n}{D} \\
\frac{\mathscr{Z}}{0} \\
0\end{array}$} & \multirow{2}{*}{$1^{+}$} & $\mathrm{M}$ & 16.75 & 16.15 & 0.42 & 0.29 \\
\hline & & $\mathrm{F}$ & 15.91 & 15.24 & 1.02 & 0.92 \\
\hline & \multirow{2}{*}{$2^{+}$} & M & 22.83 & 22.58 & 0.59 & 0.12 \\
\hline & & $\mathrm{F}$ & 21.21 & 21.21 & 0.92 & 1.53 \\
\hline & \multirow{2}{*}{$3^{+}$} & $\mathrm{M}$ & 26.57 & 26.32 & 1.34 & 1.35 \\
\hline & & $\mathrm{F}$ & 24.80 & 24.15 & 1.22 & 2.34 \\
\hline & $4^{+}$ & $\mathrm{M}$ & 28.44 & 28.20 & 0.66 & 0.84 \\
\hline & $5+$ & $\mathrm{M}$ & 30.15 & 30.04 & 0.91 & 0.27 \\
\hline \multirow{8}{*}{$\frac{\mathscr{e}}{\tilde{\tilde{J}}}$} & \multirow{2}{*}{$1^{+}$} & $\mathrm{M}$ & 15.94 & 15.54 & 0.26 & 0.08 \\
\hline & & $\mathrm{F}$ & 15.36 & 15.35 & 0.09 & 1.03 \\
\hline & \multirow{2}{*}{$2^{+}$} & M & 21.68 & 21.20 & 1.17 & 1.92 \\
\hline & & $\mathrm{F}$ & 20.31 & 20.30 & 1.11 & 1.42 \\
\hline & \multirow{2}{*}{$3^{+}$} & $\mathrm{M}$ & 25.44 & 25.31 & 0.28 & 0.28 \\
\hline & & $\mathrm{F}$ & 24.33 & 24.29 & 0.88 & 0.99 \\
\hline & $4^{+}$ & M & 28.24 & 28.12 & 0.82 & 1.92 \\
\hline & $5^{+}$ & $\mathrm{M}$ & 30.07 & 30.01 & 1.31 & 3.12 \\
\hline
\end{tabular}

$\mathrm{RM}=$ reading method, $\mathrm{M}=$ males, $\mathrm{F}=$ females, $\mathrm{t}$ : $t$-test, $P=$ significance level.

Table 5

Von Bertalanffy growth and growth performance indexes $(\varphi)$ of peacock wrasse, Symphodus tinca, from different areas

\begin{tabular}{llcccccccl}
\hline Locality & Method & Sex & Age & $L_{\infty}$ & $k$ & $t_{0}$ & $\varphi$ & $N$ & Reference \\
\hline \multirow{2}{*}{ Black Sea } & Scale & F & & 21.4 & 0.19 & & 1.93 & & Kalinina 1963 \\
& Scale & M & & 28.4 & 0.18 & & 2.17 & & \\
\multirow{2}{*}{ Southern France } & Scale & F & & 24.8 & 0.24 & & 2.18 & & Quignard 1966 \\
& Scale & M & & 31.3 & 0.25 & & 2.39 & & \\
N-W Mediterranean & Otolith & All & $1-8$ & 30.65 & 0.88 & -0.32 & 2.92 & 291 & Gordoa et al. 2000 \\
M-E Adriatic & Otolith & F & $1-12$ & 28.14 & 0.29 & -0.77 & 2.36 & 595 & Pallaoro and Jardas 2003 \\
(Croatian coast) & Otolith & $\mathrm{M}$ & $1-13$ & 42.24 & 0.21 & -0.62 & 2.58 & 848 & \\
& Otolith & $\mathrm{F}$ & $1-3$ & 26.46 & 0.79 & -0.12 & 2.74 & 277 & Presently reported study \\
\multirow{2}{*}{ Eastern Algeria } & Scale & $\mathrm{F}$ & $1-3$ & 26.61 & 0.61 & -0.45 & 2.63 & 232 & \\
& Otolith & $\mathrm{M}$ & $1-5$ & 32.32 & 0.54 & -0.22 & 2.75 & 209 & \\
& Scale & $\mathrm{M}$ & $1-5$ & 32.50 & 0.48 & -0.31 & 2.70 & 173 & \\
\hline
\end{tabular}

$\mathrm{N}-\mathrm{W}=$ north-western, $\mathrm{M}-\mathrm{E}=$ middle eastern, $\mathrm{F}=$ females, $\mathrm{M}=$ males, All $=$ all fish, $L_{\infty}=$ asymptotic mean length, $k=$ growth rate, $t_{0}=$ hypothetic age at zero length, $\varphi=$ growth performance index, $N=$ number of fish sampled. 
Table 6

Parameters of the length-weight relation of peacock wrasse, Symphodus tinca, from different areas

\begin{tabular}{lccccccl}
\hline Locality & Sex & $N$ & $A$ & $b$ & $s$ & $R^{2}$ & Reference \\
\hline Greek waters & $\mathrm{F}+\mathrm{M}$ & 31 & & 3.06 & & & Petrakis and Stergiou 1995 \\
Croatian waters & $\mathrm{F}+\mathrm{M}$ & 100 & & 2.72 & & & Dulčić and Kraljević 1996 \\
N-W Mediterranean & $\mathrm{F}+\mathrm{M}$ & 292 & 0.29 & 2.79 & 0.09 & 0.96 & Gordoa et al. 2000 \\
E-C Iberian Peninsula & $\mathrm{F}+\mathrm{M}$ & 375 & 0.01 & 2.87 & 0.09 & 0.99 & Morey et al. 2003 \\
M-E Adriatic, Croatian & $\mathrm{M}$ & 848 & 0.02 & 2.72 & 0.01 & 0.98 & Pallaoro and Jardas 2003 \\
coast & $\mathrm{F}$ & 595 & 0.01 & 2.99 & 0.02 & 0.98 & \\
İzmir Bay, Turkey & $\mathrm{F}+\mathrm{M}$ & 277 & 0.01 & 2.90 & 0.05 & 0.98 & İlhan et al. 2008 \\
Eastern Algeria & $\mathrm{F}$ & 303 & 0.01 & 3.01 & 0.05 & 0.92 & Presently reported study \\
& $\mathrm{M}$ & 227 & 0.02 & 2.86 & 0.04 & 0.91 & \\
\hline
\end{tabular}

$\mathrm{N}-\mathrm{W}=$ north-western, $\mathrm{E}-\mathrm{C}=$ eastern coast, $\mathrm{M}-\mathrm{E}=$ middle eastern, $\mathrm{F}=$ females, $\mathrm{M}=$ males, $N=$ number of fish sampled, $a=$ intercept, $b=$ slope (fish growth rate), $s=$ standard error of the slope.

respectively. Pallaoro and Jardas (2003) reported a maximum of $13^{+}$years $(42.5 \mathrm{~cm})$ for males and $12^{+}$years $(28.9$ $\mathrm{cm})$ for females in the middle-eastern Adriatic. Gordoa et al. (2000) found the maximum age to be $8^{+}$years for a peacock wrasse population (sex combined) in an area of the north-western Mediterranean coast (Catalan coast). Gordoa et al. (2000) also mentioned that the growth pattern was difficult to describe by the von Bertalanffy (1938) growth equation because of an extremely high dispersion in the length-at-age distribution.

The comparison of the growth parameters $\left(L_{\infty}, k, t_{0}\right.$, and $\varphi$ ) of the peacock wrasse from Algeria to those estimated in the north Mediterranean also showed considerable differences (Table 5). The growth performance index $(\varphi)$ was lower than that reported from the north-western Mediterranean (Gordoa et al. 2000) but higher than the values from the middle eastern Adriatic (Pallaoro and Jardas 2003), north-western Mediterranean (Quignard 1966), and Black Sea (Kalinina 1963). Regional differences in age and growth depend on the ecological conditions in the areas of investigation. Water temperature can directly affect fish growth by influencing the physiology of the fish (Weatherley and Gill 1987). However, this parameter is also directly related to rates of biological production and hence to food availability (Elizarov 1965) and benthos species composition, both of which influence fish growth.

The peacock wrasse from eastern Algeria showed negative allometric growth in males and isometric growth in females. The comparison of $b$ values for Symphodus tinca in this study are different from those obtained by other authors in the Mediterranean Sea (Table 6). İlhan et al. (2008), Morey et al. (2003), and Gordoa et al. (2000) reported these growth types from İzmir Bay, eastern Coasts of Iberian Peninsula, and north-western Mediterranean, respectively, as negative allometric growth for this species. The length-weight relation in the middle-eastern Adriatic (Croatian Coast), show that growth was negative allometric growth in males $(b=$ 2.72) and isometric in females $(b=2.99)$ (Pallaoro and
Jardas 2003). Variations should be attributed to different stages in ontogenetic development, as well as to differences in condition, sex, and maturity. Geographic location and associated environmental conditions, such as seasonality (date and time of capture), stomach fullness, disease, and parasite loads can also affect the value of $b$ (Le Cren 1951, Bagenal and Tesch 1978).

Otolithometry and scalimetry used in age determination of Symphodus tinca in eastern Algeria yielded comparable results. Future research on the growth of this species can use either of these methods, but we recommend the scales because of they are easy to collect. The growth pattern is well described by the von Bertalanffy (1938) growth equation. In general, Symphodus tinca growth is higher in eastern Algeria than in the other Mediterranean localities, depending on the ecological conditions in the study area.

\section{ACKNOWLEDGEMENTS}

The authors thank the Algerian Ministry for Higher Education and Scientific Research (General Directorate for Scientific Research and Technology Development, GDRSDT) which financially supported this study, within the framework of the National Funds of Research (NFR).

\section{REFERENCES}

Bagenal T.B., Tesch F.W. 1978. Age and growth. Pp. 101-136. In: Bagenal T.B. (ed.) Methods for assessment of fish production in fresh waters. 3rd edn. IBP Handbook No. 3. Blackwell Scientific Publications, Oxford, London, Edinburgh, Melbourne.

Bauchot M.-L. 1987. Poissons osseux. Pp. 891-1421. In: Fischer W., Bauchot M.-L., Schneider M. (eds.) Fiches FAO d'identification pour les besoins de la pêche. (rev. 1). Méditerranée et mer Noire. Zone de pêche 37. Vol. 2. Commission des Communautés Européennes and FAO, Rome.

Beamish R.J., Fournier D.A. 1981. A method for comparing the precision of a set of age determinations. Canadian Journal of Fisheries and Aquatic Sciences 38 (8): 982-983. DOI: $10.1139 / \mathrm{f} 81-132$ 
Beamish R.J., McFarlane G.A. 1983. Validation of age determination estimates: The forgotten requirement. Pp. 29-33. In: Prince E.D., Pulos L.M. (eds.) Proceedings of the international workshop on age determination of oceanic pelagic fishes: tunas, billfishes, and sharks; 15-18 February 1982, Miami, FL, USA. NOAA Technical Report NMFS 8.

Campana S.E. 2001. Accuracy, precision and quality control in age determination, including a review of the use and abuse of age validation methods. Journal of Fisheries Biology 59 (2): 197-242. DOI: 10.1111/j.1095-8649.2001.tb00127.x

Carlander J.M. 1987. A history of scale age and growth studies of North American freshwater fish. Pp. 3-14. In: Summerfelt R.C., Hall G.E. (eds.) Age and growth of fish. Iowa State University Press, Ames, IA, USA.

Caselle J.E., Hamilton S.L., Schroeder D.M., Love M.S., Standish J.D., Rosales-Casián J.A., Sosa-Nishizaki O. 2011. Geographic variation in density, demography, and life history traits of a harvested, sex-changing, temperate reef fish. Canadian Journal of Fisheries and Aquatic Sciences 68 (2): 288-303. DOI: 10.1139/F10-140

Casselman J.M. 1987. Determination of age and growth. Pp. 209-242. In: Weatherley A.H., Gill H.S. (eds.) The biology of fish growth. Academic Press, London, UK.

Chang W.Y.B. 1982. A statistical method for evaluating the reproducibility of age determination. Canadian Journal of Fisheries and Aquatic Sciences 39 (8): 1208-1210. DOI: 10.1139/f82-158

Dagnelie P. 1975. Theorie et methodes statistiques, Applications agronomiques. Vol. 2. Les methodes de l'interferene statistique. 2e ed. Presses agronomiques de Gembloux, Gembloux, Belgique.

Dieuzeide R., Novella M., Roland J. 1955. Catalogue des poissons des côtes algériennes. Vol. 3. Ostéoptérygiens (suite et fin). Bulletin des Travaux publies par la Station d'Aquaculture et de Pêche de Castiglione.

Dulčić J., Kraljević M. 1996. Weight-length relationships for 40 fish species in the eastern Adriatic (Croatian waters). Fisheries Research 28 (3): 243-251. DOI: 10.1016/01657836(96)00513-9

Elizarov A.A. 1965. Long-term variations of oceanographic conditions and stocks of cod observed in the areas of west Greenland, Labrador and Newfoundland. International Commission for the Northwest Atlantic Fisheries Special Publication No. 6. 827-831.

Fischer W., Bauchot M.-L., Schneider M. (eds.)1987. Fiches FAO d'identification des espèces pour les besoins de la pêche. Méditerranée et mer Noire; Zone de pêche 37; Révision 1. Vol. 2. Vertébrés. FAO, Rome.

Frehi H., Couté A., Mascarell G., Perrette-Gallet C., Ayada M., Kara M.H. 2007. Dinoflagellés toxiques et/ou responsables de blooms dans la baie d'Annaba (Algérie). Comptes Rendus Biologies 330 (8): 615-628. DOI: 10.1016/j.crvi.2007.05.002

Gayanilo F.C. Jr., Sparre P., Pauly D. 1996. FAO-ICLARM stock assessment tools (FISAT). User's guide. FAO Computerized Information Series (Fisheries). No. 8, Rome, FAO.

Gordoa A., Molí B., Raventós N. 2000. Growth performance of four wrasse species on the north-western Mediterranean coast. Fisheries Research 45 (1): 43-50. DOI: 10.1016/ S0165-7836(99)00094-6

Guidetti P. 2000. Differences among fish assemblages associated with nearshore Posidonia oceanica seagrass beds, rockyalgal reefs and unvegetated sand habitats in the Adriatic Sea. Estuarine, Coastal and Shelf Science 50 (4): 515-529. DOI: 10.1006/ecss. 1999.0584

İlhan (Uçkun) D., Akalın S., Tosunoğlu Z., Özaydın O. 2008. Length-weight relationships of five Symphodus species (Pisces: Perciformes) from İzmir Bay, Aegean Sea. Ege Journal of Fisheries and Aquatic Sciences 25 (3): 245-246.

Kalinina È.M. 1963. Rost i pitanie černomorskih zelenušek rodov Crenilabrus i Symphodus. [Growth and feeding of Crenilabrus and Symphodus.] Trudy Sevastopol'skoj biologičeskoj stancii 16: 323-326. [In Russian.]

Karakulak F.S., Erk H., Bilgin B. 2006. Length-weight relationships for 47 coastal fish species from the northern Aegean Sea, Turkey. Journal of Applied Ichthyology 22 (4): 274-278. DOI: 10.1111/j.1439-0426.2006.00736.x

Le Cren E.D. 1951. The length-weight relationship and seasonal cycle in gonad weight and condition in the perch (Perca fluviatilis). Journal Animal Ecology 20 (2): 210-219. DOI: 10.2307/1540

Lee R.M. 1920. A review of the methods of age and growth determination in fishes by means of scales. Fishery Investigations, Series 24 (2): 1-32.

Morey G., Moranta J., Massutí E., Grau A., Linde M., Riera F., Morales-Nin B. 2003. Weight-length relationships of littoral to lower slope fishes from the western Mediterranean. Fisheries Research 62 (1): 89-96. DOI: 10.1016/S0165-7836(02)00250-3

Pallaoro A., Jardas I. 2003. Some biological parameters of the peacock wrasse, Symphodus (Crenilabrus) tinca (L. 1758) (Pisces: Labridae) from the middle eastern Adriatic (Croatian coast). Scientia Marina 67 (1): 33-41.

Pauly D., Munro J.L. 1984. Once more on the comparison of growth in fish and invertebrates. Fishbyte 2 (1): 21.

Petrakis G., Stergiou K.I. 1995. Weight-length relationships for 33 fish species in Greek waters. Fisheries Research 21 (3-4): 465-469. DOI: 10.1016/0165-7836(94)00294-7

Quignard J.-P. 1966. Recherches sur les Labridae (Poissons, Téléostéens, Perciformes) des côtes européennes: systématique et biologie. Editions Causse et Castelnau, Naturalia Monspeliensia, Série Zoologie, Fascicule 5: 7-247.

Quignard J.-P., Pras A. 1986. Labridae. Pp. 919-942. In: Whitehead P.J.P., Bauchot M.-L., Hureau J.-C., Nielsen J., Tortonese E. (eds.) Fishes of the north-eastern Atlantic and the Mediterranean. Vol. 2. UNESCO, Paris.

Svetovidov A.N. 1964. Ryby Čërnogo Morâ. [Fishes of the Black Sea.] Opredelitel' Fauny SSSR. [Key to fauna of the SSSR.] Izdatel'stvo Nauka, Moskva.

Tortonese E. 1975. Osteichthyes; Pesci ossei (parte seconda). Fauna d'Italia. Vol 11. Calderini, Bologna, Italy.

Tsikliras A.C., Stergiou K.I., Froese R. 2013. Editorial note on reproductive biology of fishes. Acta Ichthyologica et Piscatoria 43 (1): 1-5. DOI: 10.3750/AIP2013.43.1.01

von Bertalanffy L. 1938. A quantitative theory of organic growth (inquiries on growth laws II). Human Biology 10 (2): 181-213.

Warner R.R., Lejeune P. 1985. Sex change limited by paternal care: A test using four Mediterranean labrid fishes, genus 
Symphodus. Marine Biology 87 (1): 89-99. DOI: 10.1007/ BF00397010

Weatherley A.H., Gill H.S. 1987. The biology of fish growth. Academic Press, Orlando, FL, USA.

Weijerman M., Fulton E.A., Parrish F.A. 2013. Comparison of coral reef ecosystems along a fishing pressure gradient.
PLoS ONE 8 (5): e63797. DOI: 10.1371/journal.pone. 0063797

Received: 28 January 2014

Accepted: 26 August 2014

Published electronically: 31 December 2014 